\title{
Reasons and Barriers to Lose Weight: Obese Adolescents' Point of View
}

\author{
Mara Cristina Lofrano-Prado ${ }^{1}$, James O. Hill ${ }^{2}$, \\ Humberto José Gomes Silva ${ }^{3}$, Camila Rodrigues Menezes de Freitas ${ }^{3}$, \\ Clara Maria Silvestre Monteiro de Freitas ${ }^{3}$ \\ Moacir de Novaes de Lima Ferreira ${ }^{4}$ and Wagner Luiz do Prado ${ }^{1 *}$ \\ ${ }^{1}$ Post Graduate Program of Nutrition, Federal University of Pernambuco, Brazil. \\ ${ }^{2}$ Anschutz Center for Health and Wellness, University of Colorado Denver, USA. \\ ${ }^{3}$ Physical Education Post Graduate Program, University of Pernambuco, Brazil. \\ ${ }^{4}$ Faculty of Medical Science, University of Pernambuco, Brazil.
}

Authors' contributions

This work was carried out in collaboration between all authors. Author MCLP conceptualized and designed the study, contributed to acquisition and analysis of data, drafted the initial manuscript, and approved the final manuscript as submitted. Author $\mathrm{JOH}$ conceptualized

and designed the study, reviewed and revised the manuscript, and approved the final manuscript as submitted. Authors HJGS and CRMF contributed to the interpretation of the data, critical evaluation of the manuscript, and approved the final draft of the manuscript. Authors CMSMF and MNLF revised the manuscript, and approved the final manuscript as submitted. Author WLP conceptualized and designed the study, carried out the analyses, drafted the initial manuscript, and approved the final manuscript as submitted. All authors read and approved the final manuscript.

Research Article

Received $13^{\text {th }}$ October 2012

Accepted 23 $3^{\text {rd }}$ January 2013

Published $27^{\text {th }}$ February 2013

\section{ABSTRACT}

Aims: To identify the reasons why obese adolescents seek weight loss therapy and what barriers they face in losing weight.

Study Design: Cross-sectional study.

Place and Duration of Study: Department of Physical Education and School Medical Science, University of Pernambuco 2009-11.

Methodology: The study was conducted with 128 obese adolescents (76 girls $[\mathrm{BMI}=35.46 \pm 3.92]$ and 52 boys $[\mathrm{BMl}=33.70 \pm 2.88])$, aged between 12 to 18 years old. 
Personal reasons for seeking weight loss treatment and barriers to losing weight were obtained by an individual semi-structured interview (8 questions) conducted by a psychologist. All individual interviews lasted approximately $20 \mathrm{~min}$ and were performed in a quiet room. Adolescents' answers were semi-transcribed by the researcher and the content was anonymously analyzed in order to categorize the data.

Results: The main reason for girls to start a weight loss program was to become healthy $(39.47 \%)$, followed by to fit in clothes $(30.26 \%)$, personal appearance $(30.26 \%)$, and bullying $(28.95 \%)$. Physical fitness $(40.38 \%)$ was the most important reason to seek weight loss for boys, followed by to become healthy (36.54\%), and bullying (25\%). For both genders, the main barriers described were lack of self-control $(47.37 \%-36.54 \%)$, lack of social support $(27.63 \%-30.77 \%)$, and self-motivation $(22.37 \%-21.15 \%)$.

Conclusion: Obese adolescents had several reasons for seeing weight loss. Overall, becoming healthy was the main motivation for weight loss and lack of self-control was the main barrier. This information can be used to help develop more effective weight loss strategies for obese adolescents.

Keywords: Motivation; health; obesity; weight loss; childhood.

\section{INTRODUCTION}

Clinically significant weight loss can be produced by increasing physical activity and decreasing energy intake. Weight loss outcomes are better the longer the therapy [1-3], but adherence to longer therapy requires higher levels of motivation from patients. Additionally, expectations for weight loss can affect adherence to therapy. In particular disparities between patients' goals and success in losing weight can reduce an individual's willingness to stay with long-term treatment [4].

It is important to note that intrinsic motivation (characterized by feelings of autonomy, selfdetermination and high sense of volition) has been found to be a powerful predictor of long term weight management in adults [5,6]. In adults, concerns about health appear to be the most common motivators, followed by concerns about appearance [7]. Women are more likely to be motivated by appearance, while men are more likely to lose weight to improve health and fitness [8]. A person seeking to lose weight primarily for appearance could have a different set of psychosocial characteristics and expectations than a person whose primary reason is to lose weight to improve healthy [9]. These characteristics and expectations could impact treatment success.

Overweight prevalence has increased from $4.0 \%$ to $13 \%$ among Brazilian adolescents over the last decade [10]. Very little is known about the reasons why obese and overweight adolescents want to lose weight, and their intrinsic an extrinsic motivators could vary greatly [11]. The aim of this study was to identify the reasons why obese adolescents seek weight loss therapy and what barriers they face to lose weight.

\section{METHODS}

\subsection{Participants}

Seeking weight loss treatment in the Multidisciplinary Obesity Intervention Program outpatient clinic at the University of Pernambuco/Brazil in 2011. Adolescents were between 
the ages of 12 and 18 years with a body mass index $(\mathrm{BMI}) \geq 95^{\text {th }}$ percentile [12], and pubertal stage 3 or 4 (Tanner scale) [13]. The study was formally approved by the ethics committee of the University of Pernambuco (154/09). Informed consent was obtained from all subjects and/or their parents.

\subsection{Study Protocol}

At first contact, a confidential 20-min semi-structured interview was conducted with each subject in a quiet room by a psychologist. The Interview contained 8 questions aimed to assess personal motives for seeking weight loss treatment and barriers to losing weight.

Questions asked during the interview

1. Why are you here today? Was it your decision or someone else's?

2. On a scale from zero to ten, how interested are you in engaging in an exercise program and changing your eating habits?

3. What are your personal motivations to lose weight?

4. On a scale from zero to ten, how much do you believe you are able to change your lifestyle?

5. What are the main barriers preventing you from changing your lifestyle and weight?

6. How do you deal with the fact that you will have to give up things that you like in order to reach your goal?

7. Is it your main target to lose weight with this therapy? If you are not successful, what will you do?

8. What would make you drop out the therapy?

\subsection{Anthropometric Measurements}

Subjects wearing light clothing and no shoes were weighed on a TMFilizola scale to the nearest $0.1 \mathrm{~kg}$. Height was measured to the nearest $0.5 \mathrm{~cm}$ by using a wall-mounted stadiometer (Sanny, model ES 2030). BMI was calculated as body weight divided by height squared.

\subsection{Data Analysis}

During the interviews, the researcher semi-transcribed the adolescents' answers and afterwards (on a different day) conducted an analysis of contents [14]. The aim to identify common themes which were used to code elements of the data. These were expressed as answer frequency (\%). Differences between boys and girls were assessed by chi-square. Comparisons between genders for continuous variables (age and anthropometrical data) were made using independent T-test and presented as means \pm SD. Significance were set at $p \leq 0.05$. All data were analyzed by STATISTICA 8.0 for Windows.

\section{RESULTS}

In this study, the sample was composed of 76 girls (59.4\%) and 52 boys (40.6\%). Table 1 shows anthropometrical characteristics of the subjects. No differences were observed in age between genders $(p=.06)$. As expected, boys were heavier $(p=.04)$ and taller $(p=.00)$ than girls, however females showed higher BMI than males $(p=.00)$. 
Table 1. Descriptive characteristics of 196 obese adolescents seeking weight loss therapy

\begin{tabular}{llll}
\hline Variables & All $(\mathbf{n}=\mathbf{1 9 6})$ & Girls $(\mathbf{n}=\mathbf{1 2 1})$ & Boys $(\mathbf{n}=\mathbf{7 5})$ \\
\hline Age $(\mathrm{y})$ & $15.43 \pm 1.57$ & $15.64 \pm 1.57$ & $15.10 \pm 1.54$ \\
Height $(\mathrm{m})$ & $1.63 \pm 0.07$ & $1.60 \pm 0.06$ & $1.68 \pm 0.06^{*}$ \\
Body Mass $(\mathrm{Kg})$ & $93.00 \pm 11.18$ & $91.50 \pm 11.27$ & $95.42 \pm 10.69^{*}$ \\
BMI $\left(\mathrm{Kg} / \mathrm{m}^{2}\right)$ & $34.77 \pm 3.64$ & $35.46 \pm 3.92$ & $33.70 \pm 2.88^{*}$ \\
\hline
\end{tabular}

\subsection{Reasons to Lose Weight}

Obese adolescents reported many reasons to seek weight loss therapy. The most frequent answer for girls was to become healthy $(39.47 \%)$. This was followed by to fit in clothes $(30.26 \%)$, personal appearance $(30.26 \%)$, bullying $(28.95 \%)$, and self-esteem $(26.32 \%)$. Physical fitness $(40.38 \%)$ was the most frequent reason that led boys seek therapy, followed by to become healthy (36.54\%), bullying $(25 \%)$, and self-esteem $(19.23 \%)$. Boys and girls differed only in physical fitness $(p=.00)$ and body shame $(p=.04)$. It is important to note that only a few obese adolescents reported quality of life as a major factor for losing weight ( 3 boys and 0 girls) (Fig. 1). Table 2 presents some of adolescents' responses to the questions.

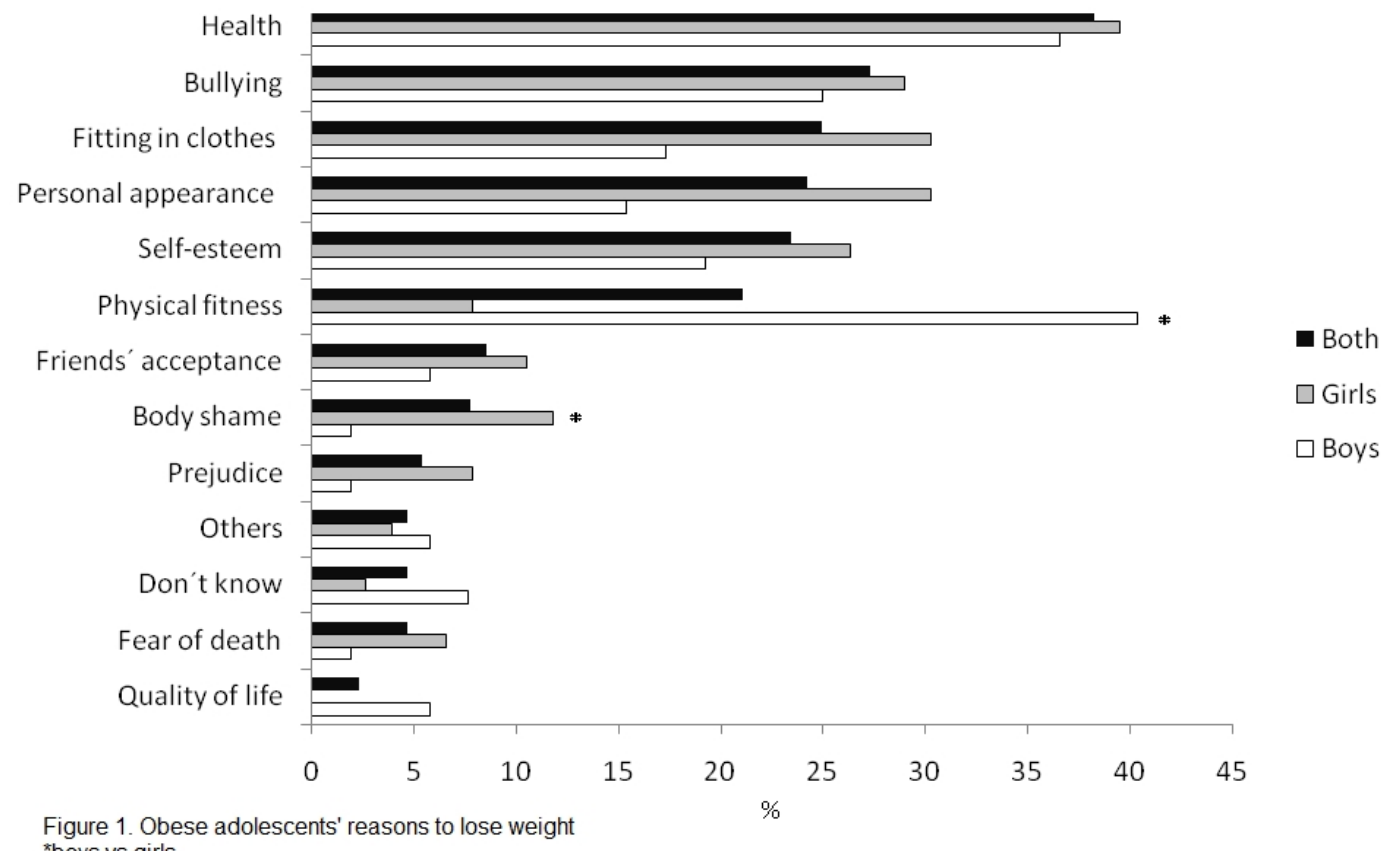

Fig. 1. Obese adolescents' reasons to lose weight "boys vs girls" 
Table 2. Examples of adolescents' responses to the motivation questions

\begin{tabular}{|c|c|c|}
\hline Reason & Example 1 & Example 2 \\
\hline Health & $\begin{array}{l}\text { "...some of my relatives are } \\
\text { obese, I don't want have diabetes } \\
\text { or heart diseases..." }\end{array}$ & $\begin{array}{l}\text { "...my daddy had a heart } \\
\text { attack and my mommy has } \\
\text { heart problems, I am afraid } \\
\text { to go in the same way ...". }\end{array}$ \\
\hline Bullying & $\begin{array}{l}\text { "...my aunt and sisters call me fat } \\
\text { and ugly.." }\end{array}$ & $\begin{array}{l}\text { "...at school, other } \\
\text { students call me by } \\
\text { nicknames and make } \\
\text { stupid jokes about my } \\
\text { size; }\end{array}$ \\
\hline Fitting in clothes & $\begin{array}{l}\text { "...it is hard to buy clothes, } \\
\text { nothing looks good on my body..." }\end{array}$ & $\begin{array}{l}\text { "...All t-shirts are too small } \\
\text { for me, it is too bad..." }\end{array}$ \\
\hline Personal appearance & $\begin{array}{l}\text { "..." I hate the mirror, it is } \\
\text { disgusting when I see my image } \\
\text { at the mirror..." }\end{array}$ & $\begin{array}{l}\text { "...When I was child, I } \\
\text { used to be model, and } \\
\text { now they don't want me } \\
\text { more on the runways..." }\end{array}$ \\
\hline Self-steem & $\begin{array}{l}\text { "...I want to feel good with myself. } \\
\text { I feel terrible because I am not } \\
\text { able to do anything..." }\end{array}$ & $\begin{array}{l}\text { "...I don't want leave my } \\
\text { home. Nothing about me } \\
\text { attracts other people..." }\end{array}$ \\
\hline Physical Fitness & $\begin{array}{l}\text { "... I want play sports with my } \\
\text { friends, but I feel tired and have } \\
\text { no sports ability..." }\end{array}$ & $\begin{array}{l}\text { "...I feel I am getting } \\
\text { separated from my friends, } \\
\text { once I can't play soccer } \\
\text { with them..." }\end{array}$ \\
\hline
\end{tabular}

\subsection{Barriers to Lose Weight}

The main barriers to seeking weight loss treatment in both girls and boys were lack of selfcontrol $(47.37 \%-36.54 \%)$, lack of social support $(27.63 \%-30.77 \%)$, and lack of selfmotivation $(22.37 \%-21.15 \%)$. Difficulty of changing was reported by $19.23 \%$ of boys and anxiety was reported by $13.16 \%$ of girls (Fig. 2). Laziness was the only barrier that differed between genders $(p=.04)$ with girls listing this more frequently than boys. Responses to the barriers questions are shown in Table 3.

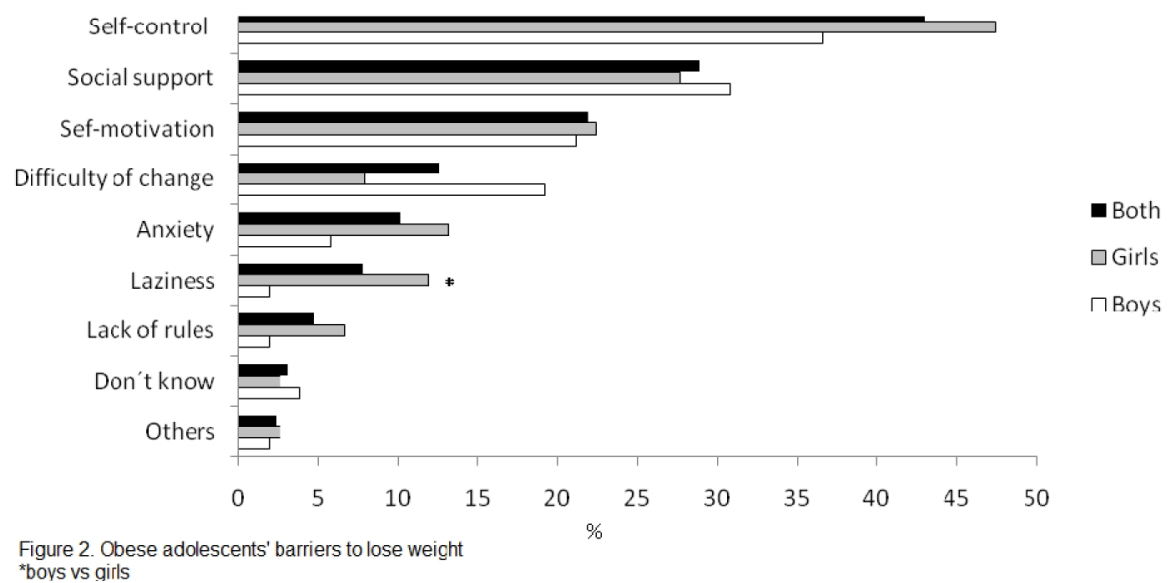

Fig. 2. Obese adolescents' barriers to lose weight "boys vs girls" 
Table 3. Examples of adolescents' responses to the barriers questions

\begin{tabular}{|c|c|c|}
\hline Reason & Example 1 & Example 2 \\
\hline Self-control & $\begin{array}{l}\text { "I know I shouldn't eat too much, but } \\
\text { when I start to eat at night I can't stop" }\end{array}$ & $\begin{array}{l}\text { "...I tried to lose weight } \\
\text { before, but quit. My brothers } \\
\text { are obese too, and when they } \\
\text { start to eat, I eat with them..." }\end{array}$ \\
\hline Social support & $\begin{array}{l}\text { "... My daddy says that it will not work, } \\
\text { that I will not be successful..." }\end{array}$ & $\begin{array}{l}\text { "... it is hard exercising alone, } \\
\text { because you don't have } \\
\text { someone to talk to..." }\end{array}$ \\
\hline $\begin{array}{l}\text { Self- } \\
\text { motivation }\end{array}$ & $\begin{array}{l}\text { "... definitely I have no willpower, but I } \\
\text { want to believe.... talk is easy, but it is } \\
\text { hard to do..." }\end{array}$ & $\begin{array}{l}\text { "...It is impossible to keep } \\
\text { going, this time will not be } \\
\text { different..." }\end{array}$ \\
\hline
\end{tabular}

\section{DISCUSSION}

We identified reasons why obese Brazilian adolescents seek weight loss therapy and their perceived barriers to success. The main results are: 1) Both boys and girls stated that the most important reason to lose weight is to become healthy; 2) Boys were worried about physical fitness while girls had profound body shame; and 3) Absence of self-control was the main barrier to success in obesity therapy for adolescents.

Improving health was the most frequent reason for losing weight in girls and the second most frequent reason for boys in the present study. Improving health seems to be important for adults and adolescents. It has been reported that motivation for weight loss in obese adults can divided into three broad categories: health (50\%), appearance (35\%) and mood $(15 \%)$ [9]. However, men report health problems more as a trigger to lose weight than women [15]. We found that boys, much more than girls, are driven by a desire to become fit rather than just healthy. Improving fitness may not be a frequent reason for weight loss in adult men [16].

The desire to be more attractive and fitting in clothes were the next most frequent reasons for weight loss listed by girls. Personal appearance is often reported as a reason to lose weight [7]. Attractive individuals have advantages in employment, marriage, and other life outcomes [17,18], and are seen as happier, and more talented than other people. One study found that in obese 8 to 14 year-old children, a desire to "fit in" was an important reason for weight loss. Moreover, this desire stemmed not from a need to be "perfect", but from a desire to be "normal", to "blend in" with their peers so as not to be considered different and to suffer negative social consequence.

Improving self-esteem was listed as a frequent reason for weight loss for girls and boys. Obese children have consistently been shown to have lower self-esteem specifically related to their physical appearance and report higher levels of body dissatisfaction than non-obese children [19,20]. Lofrano-Prado et al. [21] showed that, in response to multidisciplinary therapy, obese adolescents improved self-esteem, quality of life and body image dissatisfaction. Those changes were not necessarily associated with weight loss.

Reducing bullying was an important reason for weight loss in girls and boys. Obese children who suffer from body dissatisfaction and low self-esteem may be at a greater risk of being bullied. When adolescents experience negative peer relationships and their weight status 
becomes the target of harassment, there can be negative short and long term effects [19]. Bullying is an aggressive behavior involving an imbalance of power between the bully and victim, and could take various forms, such as physical (e.g. hitting), verbal (e.g. calling mean names), social or relational (e.g. social exclusion and spreading rumors), or a relatively new form cyber bullying (e.g. bullying through computers or cell phones) [22]. Even slight deviations from "ideal body size" can trigger discrimination and weight bias from peers [20].

Lack of self-control was listed as the main barrier to lose weight in this population. Adults that have had previous experiences with weight loss treatment declare that the major obstacle to treatment adherence is lack of control while feeling hungry $(71.3 \%)$, followed by staying motivated to keep the weight off $(68.5 \%)$, and difficulty to eating properly $(66.2 \%)$ [23]. Self-control could be influenced by the actions of peers, voices of authority, physical inability, access to sports facilities, the expense of "healthy" school meals and area of residence were all declared as barriers that influence on children's self-control [24], and are closely related with social support.

Lack of social support was another frequent barrier to success in this study. Social support is a key component of obesity treatment $[23,25]$. With adolescents, parents may unintentionally fail to provide this support, and even could create barriers to healthy eating behavior. Adults' perceive family eating habits (eating out, unhealthy cooking styles, and unavailability of healthy food) as a central obstacle to losing weight [12]. Children identify parents' support as essential in raising their self-efficacy and keeping them motivated. Without their parents they feel success would be unlikely [26].

In the present study, the absence of measures to validate the qualitative data and the fact that the content analysis was conducted by a single researcher can be considered as limitations that should be considered in the interpretation of the results.

\section{CONCLUSION}

These results add to the growing literature on treating adolescent obesity. Here we identified reasons for weight loss and barriers to success in obese Brazilian adolescent. We believe that a better understanding of these reasons and barriers could be useful in selecting the most appropriate approach to weight loss, and could eventually improve outcomes.

\section{CONSENT}

All authors declare that 'written informed consent was obtained from the patient (or other approved parties) for publication of this case report and accompanying images.

\section{ETHICAL APPROVAL}

The study was formally approved by the ethics committee of the University of Pernambuco (154/09).

\section{ACKNOWLEDGEMENTS}

We would like to thank the Conselho Nacional de Desenvolvimento Científico e Tecnológico and the Fundação de Amparo à Ciência e Tecnologia do Estado de Pernambuco (FACEPE) 
for financial support; Thanks to Manoel Freitas by the support in the preparation of the figures. Special thanks to patients and their parents for the participation in this study.

\section{COMPETING INTERESTS}

Authors declare that there are no conflicts of interest (including financial and other relationships) for each author.

\section{REFERENCES}

1. Caranti DA, de Mello MT, Prado WL, Tock L, Siqueira KO, de Piano A, et al. Short and long-term beneficial effects of a multidisciplinary therapy for the control of metabolic syndrome in obese adolescents. Metabolism. 2007;56(9):1293-1300. DOI:10.1016/j.metabol.2007.05.004.

2. de Piano A, Prado WL, Caranti DA, Siqueira KO, Stella SG, Lofrano M, et al. Metabolic and nutritional profile of obese adolescents with nonalcoholic fatty liver disease. J Pediatr Gastroenterol Nutr. 2007;44(4):446-452. DOI:10.1097/MPG.0b013e31803815d9.

3. Prado WL, Siegfried A, Dâmaso AR, Carnier J, de Piano A, Siegfried W. Effects of long-term multidisciplinary inpatient therapy on body composition of severely obese adolescents. J Pediatr. 2009;85(3):243-248. DOI:10.2223/JPED.1889.

4. Dutton GR, Perri MG, Dancer-Brown M, Goble M, Vessem NV. Weight loss goals of patients in a health maintenance organization. Eat Behav. 2010;11(2):74-78. DOI: 10.1016/j.eatbeh.2009.09.007.

5. Teixeira PJ, Going SB, Houtkooper LB, Cussler EC, Metcalfe LL, Blew RM, et al. Exercise motivation, eating, and body image variables as predictors of weight control. $\begin{array}{lll}\text { Med Sci Sports Exerc. 2006;38(1):179-188. DOI: } & \end{array}$ 10.1249/01.mss.0000180906.10445.8d.

6. Mata J, Silva MN, Vieira PN, Carraça EV, Andrade AM, Coutinho SR, et al. Motivational "spill-over" during weight control: increased self-determination and exercise intrinsic motivation predict eating self-regulation. Health Psychol. 2009;28(6):709-716. DOI: 10.1037/a0016764

7. Brink PJ, Ferguson K. The decision to lose weight. West J Nurs Res. 1998;20(1):84102.

8. Cheskin LJ, Donze LF. Appearance vs health as motivators for weight loss. JAMA. 2001;286:2160. DOI:10.1016/j.psychsport. 2011.12.005

9. O'Brien K, Venn BJ, Perry T, Green TJ, Aitken W, Bradshaw, et al. Reasons for wanting to lose weight: different strokes for different folks. Eat Behav. 2007;8(1):132135. DOI: 10.1016/j.eatbeh. 2006.01.004.

10. da Veiga GV, da Cunha AS, Sichieri R. Trends in overweight among adolescents living in the poorest and richest regions of Brazil. Am $\mathrm{J}$ Public Health. 2004;94(9):1544-1548. DOI:10.2105/AJPH.94.9.1544.

11. Teixeira PJ, Going SB, Sardinha LB, Lohman TG. A review of psychosocial pretreatment predictors of weight control. Obes Rev. 2005;6(1):43-65. DOI: 10.1111/j.1467-789X.2005.00166.

12. Centers for Disease Control and Prevention. Prevalence of overweight among children and adolescents United States; 1999-2000. Accessed May 21 2011. Available: http://www.cdc. gov/nchs/products/pubs/pubd/hestats/overwght99.htm. 
13. Tanner JM, Whitehouse RH. Clinical longitudinal standards for height, weight, height velocity, weight velocity, and stages of puberty. Arch Dis Child. 1976;51(3):170-179. Doi:10.1136/adc.51.3.170.

14. Bardin, L. Análise de Conteúdo. Lisboa: edições 70; 1988.

15. Klem MR, Wing RR, McGuire MT, Seagle HM, Hill JO. A descriptive study of individuals, successful at long-term maintenance of substantial weight loss. Am J Clin Nutr. 1997;66(2):239-246.

16. Hankey CR, Leslie WS, Lean MEJ. Why lose weight? Reasons for seeking weight loss by overweight but otherwise healthy men. Int $\mathrm{J}$ Obes Relat Metab Disord. 2002;26(6):880-882. DOI:10.1038/sj.ijo.0801999.

17. Kwan S. Competing motivational discourses for weight loss: Means to ends and the nexus of beauty and health. Qual Health Res. 2009;19(9):1223-1233. DOI: $10.1177 / 1049732309343952$.

18. Kwan S, Trautner MN. Beauty work: Individual and institutional rewards, the reproduction of gender, and questions of agency. Soc Compass. 2009;3(1):49-71. DOI: 10.1111/j.1751-9020.2008.00179.x

19. Falkner NH, Neumark-Sztainer D, Story M, Jeffery RW, Beuhring T, Resnick MD. Social, educational and psychological correlates of weight status in adolescents. Obes Res. 2001;9(1):32-42. DOI: 10.1038/oby.2001.5

20. Farhat T, lannotti RJ, Simons-Morton BG. Overweight, obesity, youth, and health-risk behaviors. Am J Prev Med. 2010;38(3):258-267. DOI: 10.1016/j.amepre.2009.10.038

21. Lofrano-Prado MC, Antunes HK, Prado WL, de Piano A, Caranti DA, Tock L, et al. Quality of life in Brazilian obese adolescents: effects of a long-term multidisciplinary lifestyle therapy. Health Qual Life Outcomes. 2009;7:61. DOI: 10.1186/1477-7525-761.

22. Burke LE, Steenkiste A, Music E, Styn MA. A descriptive study of past experiences with weight-loss treatment. J Am Diet Assoc. 2008;108(4):640-647. DOI: 10.1016/j.jada.2008.01.012.

23. Porter JS, Bean MK, Gerke CK, Stern M. Psychosocial factors and perspectives on weight gain and barriers to weight loss among adolescents enrolled in obesity treatment. J Clin Psychol Med Settings. 2010;17(2):98-102. DOI: 10.1007/s10880010-9186-3.

24. Murtagh J, Dixey R, Rudolf M. A qualitative investigation into the levers and barriers to weight loss in children: opinions of obese children. Arch Dis Child. 2006;91(11):920923. DOI:10.1136/adc.2005.085712.

25. Stevenson C, Doherty G, Barnett J, Muldoon OT, Trew K. Adolescents' views of food and eating: Identifying barriers to healthy eating. J Adolesc. 2007;30(3):417-434. DOI:10.1016/j.adolescence.2006.04.005.

26. Smith PK, Brain P. Bullying in schools: Lessons from two decades of research. Aggress Behav. 2000;26(1):1-9. DOI: 10.1002/(SICI)1098-2337(2000)26:1<1::AID$A B 1>3.0 . C O ; 2-7$.

(c) 2013 Lofrano-Prado et al.; This is an Open Access article distributed under the terms of the Creative Commons Attribution License (http://creativecommons.org/licenses/by/3.0), which permits unrestricted use, distribution, and reproduction in any medium, provided the original work is properly cited.

Peer-review history:

The peer review history for this paper can be accessed here: http://www.sciencedomain.org/review-history.php?iid=194\&id=12\&aid=980 